\title{
New records of flowering plants collected from the Phou Khao Khouay National Biodiversity Conservation Area for the flora of Laos
}

\author{
Chang-Kun LIM, Kyoung-Eun LEE, Hyun-Sung CHO, \\ Veosavanh SAYSAVANH ${ }^{1}$ and Hyosig WON* \\ Department of Biological Science and Institute of Natural Sciences, Daegu University, Gyeongsan 38453, Korea \\ ${ }^{1}$ Protected Area Management Division, Department of Forestry, Ministry of Agriculture and Forestry, Lao PDR \\ (Received 2 September 2021; Revised 26 September 2021; Accepted 29 September 2021)
}

\begin{abstract}
We report 14 species of flowering plants as new additions to the flora of Laos. These are Illex viridis (Aquifoliaceae), Capparis erycibe (Capparaceae), Euphorbia bokorensis (Euphorbiaceae), Exacum darae (Gentianaceae), Aeschynanthus cambodiensis (Gesneriaceae), Tetraphyllum roseum (Gesneriaceae), Utricularia gibba (Lentibulariaceae), Macrosolen brandisianus (Loranthaceae), Decaschistia siamensis (Malvaceae), Nyssa yunnanensis (Nyssaceae), Adenia penangiana var. penangiana (Passifloraceae), Pentaphylax euryoides (Pentaphylacaceae), Wikstroemia bokorensis (Thymelaeaceae), and Debregeasia wallichiana (Urticaceae). We discovered the species during a botanical survey of the Phou Khao Khouay National Biodiversity Conservation Area (PKKNBCA) of Lao PDR in 2015-2019. In addition, nine rarely collected flowering plant species in Laos are newly reported for the PKKNBCA.
\end{abstract}

Keywords: unreported species, flowering plants, flora, Phou Khao Khouay National Biodiversity Conservation Area (PKKNBCA), Lao PDR

The flora of Laos is one of the least known in the region, primarily due to the lack of botanical exploration, expertise, and research, also hampered by the Indochinese wars (Newman et al., 2007). Since Newman et al. (2007) compiled a checklist for vascular plants of Lao PDR as having 5,005 species, there have been a steady increase in new records of vascular plants in Laos. For example, Lanorsavanh and Chantaranothai (2013, 2019), Lanorsavanh et al. (2020) reported new records and species of Argostemma (Rubiaceae); Leong-Škorničková et al. (2014), Newman (2015), Souvannakhoummane and LeongŠkorničková (2018), and Tanaka et al. (2020) reported new species and records of Zingiberaceae; Souvannakhoummane and Suksathan (2015) reported two new species of Impatiens (Balsaminaceae); Lim et al. (2015) reported three unrecorded species: Phyllagathis tuberosa (Melastomataceae), Tolypanthus pustulatus (Loranthaceae), and Lonicera bournei (Caprifoliaceae); Fici (2016), Fici et al. (2017, 2020), Souvannakhoummane et al. (2018), and Fici and Souvannakhoummane (2020) reported new species of Capparis (Capparaceae); Prosperi et al. (2018) reported 27 taxa from Khammouane Limestone Area (Phou Hin Poun NBCA); Rodda and Meve (2017) reported Ceropegia laotica (Apocynaceae); Souladeth et al. (2017) reported Strobilanthes namkadingensis (Acanthaceae); Suetsugu et al. (2018) reported Lecanorchis taiwaniana (Orchidaceae); Tagane et al. (2018b) reported Monoon namkadingense and Neouvaria laosensis (Annonaceae); Tagane et al. (2018a) reported 30 new records of flowering plants from Nam Kading National Protected Area; Yang et al. (2018) reported Begonia namkadingensis (Begoniaceae); Souladeth et al. (2019) reported two new species of Camellia (Theaceae); Nagahama et al. (2019) reported Gentiana bolavenensis (Gentianaceae); Souvannakhoummane et al. (2019) and Souvannakhoummane and Phonepaseuth (2020) reported new species of Didymocarpus (Gesneriaceae); Panyadee et al. (2020) reported two new records of Gesneriaceae (Damrongia trisepala and Didymocarpus formosus); Souladeth et al. (2020) reported two new records of Eriocaulon

\footnotetext{
*Author for correspondence: wonhs@daegu.ac.kr
} 


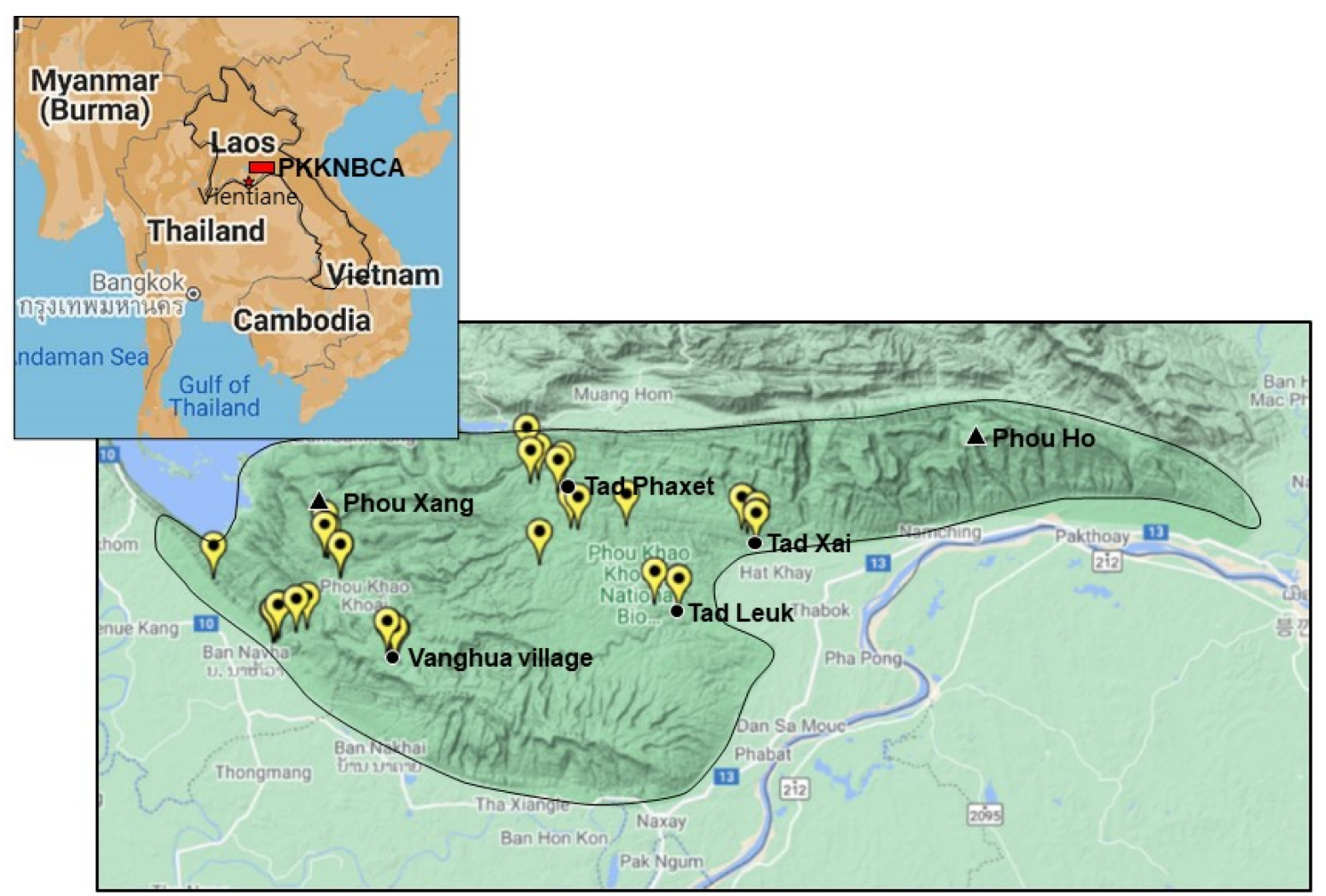

Fig. 1. Map showing the geographical location of Phou Khao Khouay National Biodiversity Conservation Area (PKKNBCA), Lao PDR, and the collection sites of the new records of flowering plants from PKKNBCA presented in this paper.

(Eriocaulaceae); Suddee et al. (2020) reported Coleus bolavenensis (Lamiaceae); Yang et al. (2020) reported a new species and two new records of Goniothalamus (Annonaceae); Tagane et al. (2020a) and Tagane et al. (2020b) successively reported new plant records from Bolaven Plataeu of southern Laos - two new species and 18 new plant records, and 25 new plant records, respectively; Tagane et al. (2020c) reported Diospyros laoensis (Ebenaceae); Phonepaseuth et al. (2021a) reported two new Sonerila species, $S$. erectifolia and $S$. souvannii (Melastomataceae); Phonepaseuth et al. (2021b) reported new species of Paraboea and Middletonia (Gesneriaceae); Souladeth et al. (2021) reported Impatiens subfalcata (Balsaminaceae); Yamazaki et al. (2021a, 2021b) reported Strobilanthes bolavenensis and Justicia vagabunda var. laxiflora (Acanthaceae), respectively. Therefore, the checklist of vascular plants of Lao PDR is continuously being updated (Newman et al., 2017-present; https://padme.rbge.org.uk/laos/).

Phou Khao Khouay National Biodiversity Conservation Area (PKKNBCA) is one of the 23 national protected areas of Lao PDR, located ca. $40 \mathrm{~km}$ northeast of Vientiane, the capital of the country (Fig. 1). PKKNBCA is stretched over Vientiane and Bolikamxai provinces, ranging from $100 \mathrm{~m}$ to $1,700 \mathrm{~m}$ in elevation. PKKNBCA ranges from evergreen dipterocarp to mixed deciduous, dry dipterocarp, and coniferous forest and fire-climax grasslands (Soukhavong et al., 2013; Nanthavong, 2015). Between December 2015 and September 2019, we collected and surveyed the area to document the seed plant biodiversity of the area, in collaboration with the Department of Forestry, Ministry of Agriculture and Forestry, of the Lao PDR. Here, we are reporting 14 flowering plant species new for the flora of Laos and nine rarely collected species that are first reported for PKKNBCA.

\section{Materials and Methods}

We surveyed PKKNBCA between December, 2015 and September, 2019 and made ca. 1,180 collections. Specimens collected from PKKNBCA are deposited at the herbarium of National Institute of Biological Resources (KB), Ministry of Environment, Republic of Korea, with duplicates stored at the herbarium of Faculty of Forestry, National University of Laos (FOF) and Daegu University herbarium (DGU). Some collections with incomplete identification are currently stored at DGU and will be deposited both at $\mathrm{KB}$ and $\mathrm{FOF}$, upon completion of 
identification.

To identify species and confirm distribution records in Laos, we first checked relevant plant taxonomic literatures in the region, such as Flore du Cambodge, du Laos et du Vietnam (Aubreville et al. 1960-present), Flora of Thailand (Smitinand and Larsen, 1970-present), and Flora of China (Wu et al., 1994-2003), and the checklist of the vascular plants of Laos (Newman et al., 2017-present; https://padme.rbge.org.uk/laos/) were consulted. We also examined specimens at the Forest Herbarium, Bangkok (BKF), Bangkok Herbarium (BK), and Queen Sirikit Botanical Garden Herbarium (QBG), especially of Melastomataceae and Gesneriaceae. We also examined specimen images available on the web, such as the JSTOR Global Plant (https://plants.jstor.org), Royal Botanical Garden Edinburgh (E), (http://data.rbge.org.uk), Museum National d'Histoire Naturelle (P), and GBIF website.

\section{Results and Discussion}

We discovered 14 species of flowering plants that are new
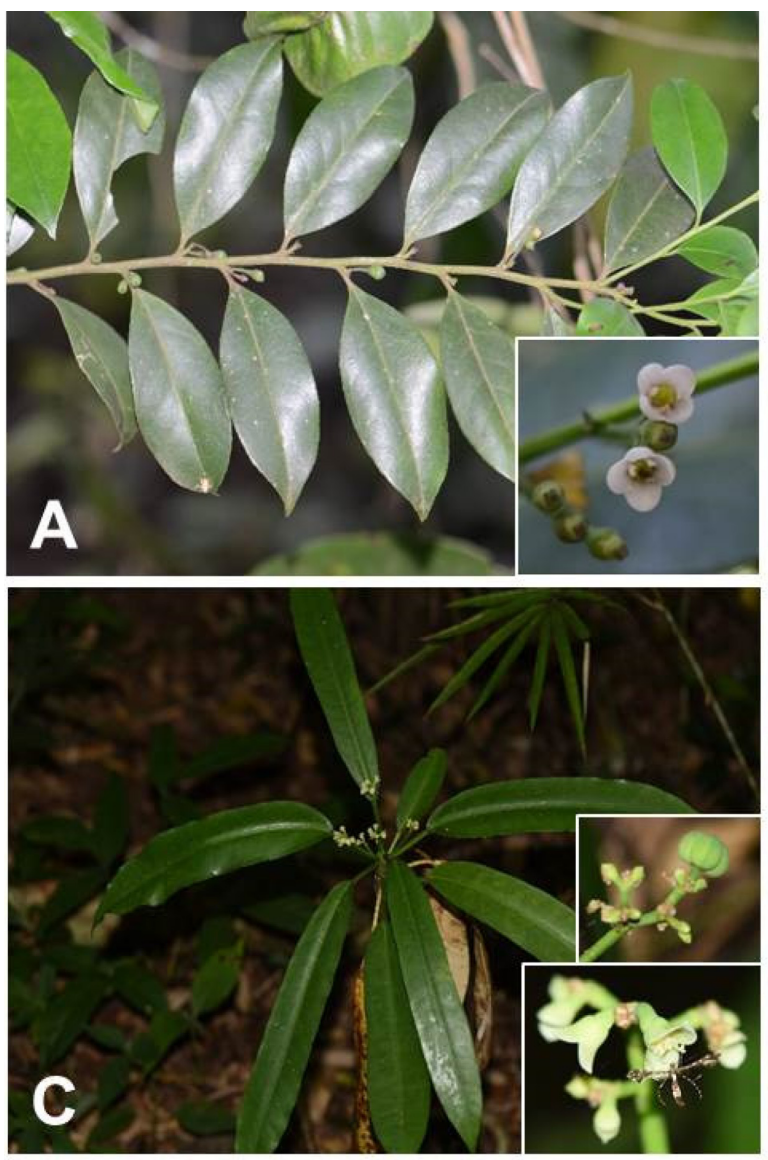

for the flora of Laos, three are known endemics to Cambodia, one to Thailand, one to China, and one to Cambodia and Thailand. The other species are fairly widely distributed in SE Asia. Also, we found nine species of flowering plants, rarely collected from Laos. Two of the nine species are only known from type localities in Laos, and the others are only enlisted in Newman et al. (2017-present) without voucher information.

\section{New flowering plant records for the flora of Laos, collected from PKKNBCA}

\section{Aquifoliaceae}

1. Ilex viridis Champ. ex Benth., Hooker's J. Bot. Kew Gard. Misc. 4: 329, 1852 (Fig. 2A).

Ilex viridis is an evergreen small tree or shrub. For the flora of Laos, three Ilex species have been reported-I. eugeniifolia Pierre, I. godajam (Colebr.) Hook. f., and I. rotunda Thunb. (Newman et al., 2017-present). Ilex viridis is characterized by its axillary, 1 to few flowered cyme.

Distribution: China, Laos, Thailand, Vietnam.
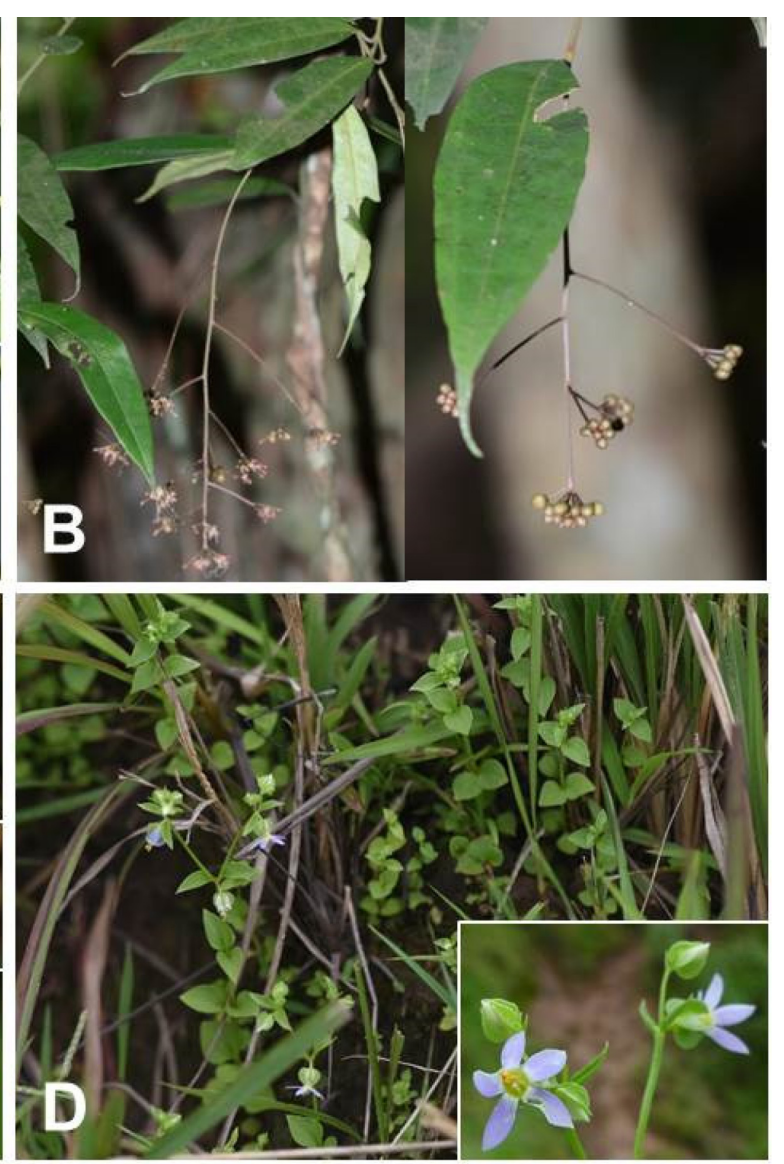

Fig. 2. New record of flowering plants for the flora of Laos (1). A. Ilex viridis Champ. ex Benth. (Aquifoliaceae). B. Capparis erycibe Hallier. f. (Capparaceae). C. Euphorbia bokorensis H. Toyama \& Tagane (Euphorbiaceae). D. Exacum darae Hul (Gentianaceae). 
Specimens examined: LAOS. Vientiane: Thoulakhom District, PKKNBCA, at the thick forest east of the Nam Mang River, at east of the Nam Mang 3 Dam, near Vang Hua village, along the trail in thick forest, $18^{\circ} 21^{\prime} 27.6^{\prime \prime} \mathrm{N}, 102^{\circ} 48^{\prime} 27.3^{\prime \prime} \mathrm{E}$, elev. 761 m, 2 Jun 2017, Hyosig Won et al. 15670 (DGU, FOF, $\mathrm{KB})$.

\section{Capparaceae}

2. Capparis erycibe Hallier. f., Bull. Herb. Boissier 6: 216, 1898 (Fig. 2B).

Capparis erycibe is a perennial climber, characterized by its inflorescences consisted of subumbels arranged in panicle and leaves elongate, obovate or oblong (Chayamarit, 1991).

Distribution: Indochina, Malay Peninsula, Sumatra, Java, Borneo, Thailand.

Specimens examined: LAOS. Bolikamxai: Thaphabat District, PKKNBCA, at the north part of the Nam Leuk Reservior, near Tad Phaxet, at the road junction between Nam Leuk and Muang Hom, at rocky area under shaded forest, $18^{\circ} 30^{\prime} 35.2^{\prime \prime} \mathrm{N}, 102^{\circ} 56^{\prime} 38.7^{\prime \prime}$, elev. $526 \mathrm{~m}, 22$ Aug 2016, Hyosig Won et al. 15418 (DGU, FOF, KB); Thaphabat District, PKKNBCA, near the Tad Xai Waterfall, $18^{\circ} 27^{\prime} 16.9^{\prime \prime} \mathrm{N}$, 10308'29.3"E, elev. 330 m, 19 Jul 2017, Hyosig Won et al. 15999 (DGU, FOF, KB).

\section{Euphorbiaceae}

3. Euphorbia bokorensis H. Toyama \& Tagane, Acta Phytotax. Geobot. 67: 92, 2016 (Fig. 2C).

Toyama et al. (2016) described E. bokorensis based on specimens collected from Bokor National Park, Cambodia. Until now, E. bokorensis has only been reported from the Bokor National Park, and the current discovery of E. bokorensis from Laos suggests that $E$. bokorensis may also be distributed widely in Indochina. It is distributed in the understory of dense humid evergreen forests along a stream leading to the Tad Xai Waterfall of PKKNBCA.

Distribution: Cambodia, Laos.

Specimens examined: LAOS. Bolikamxai: Thaphabat District, PKKNBCA, about $1.5 \mathrm{~km} \mathrm{NW}$ of the Tad Xai Waterfall, at the margin of the open rock bed, $18^{\circ} 27^{\prime} 47.2^{\prime \prime} \mathrm{N}$, 10308'03.3"E, elev. 394 m, 12 Nov 2017, Hyosig Won et al. 16236 (DGU, FOF, KB).

\section{Gentianaceae}

4. Exacum darae Hul, Edinburgh J. Bot. 67: 155, 2010 (Fig. 2D). Newman et al. (2007) reported two Exacum, E. pteranthum Wall. ex G. Don and E. tetragonum Roxb., for the flora of Laos. Hul (2010) recognized a slender and smaller form of $E$. sutapaense Hosseus ex Craib (var. gracile) as a distinct species, E. darae. Exacum darae is distributed in the Cardamom Mountains areas of Cambodia at ca. 1,000 m elevation and Me Tawn and Me Sawi (ca. 1,550-1,700 m), Doi Suthep (ca. 1,600 m), Doi Pui (ca. 1,600 m) of Chiang Mai Province and Khao Pawta Luang Keow (ca. 1,200-1,300 m) of the peninsular area of Thailand. The new collections were made from the open grassy area of Mt. Phou Xang, elevations ranging from $1,400-1,600 \mathrm{~m}$.

Distribution: Cambodia, Laos, Thailand.

Specimens examined: LAOS. Vientiane: Thoulakhom District, PKKNBCA, along the south ridge leading to the rim of Phu Xang, open grassy slopes, $18^{\circ} 26^{\prime} 27.7^{\prime \prime} \mathrm{N}, 102^{\circ} 45^{\prime} 08.5^{\prime \prime} \mathrm{E}$, elev. 1,440 m, 9 Sep 2019, Hyosig Won et al. 17058 (DGU, FOF, KB); Thoulakhom District, PKKNBCA, along the middle ridge leading to the rim of Phu Xang, open grassy area, $18^{\circ} 27^{\prime} 05.8^{\prime \prime} \mathrm{N}, 102^{\circ} 44^{\prime} 59.3$ "E, elev. 1,609 m, 9 Sep 2019, Hyosig Won et al. 17077 (DGU, FOF, KB).

\section{Gesneriaceae}

5. Aeschynanthus cambodiensis D. J. Middleton, Edinburgh J. Bot. 66: 408, 2009 (Fig. 3A).

Aeschynanthus cambodiensis has been reported as endemic of Cambodia, only collected from Ratanakiri Province so far. Aeschynanthus cambodiensis was collected from three different places in PKKNBCA during our field trip in November 2017. These collections match exactly with the description and key characteristics of $A$. cambodiensis, recognized by Middleton (2009). Compared to A. longicaulis Wall. ex R. Br., distributed in eastern Myanmar, western and southern Thailand, and Peninsular Malaysia, A. cambodiensis has glabrous calyx lobes almost the length of corolla, while A. longicaulis has calyx lobes glabrous or with sparse glandular hairs about $1 / 2$ the length of corolla (Middleton, 2016).

Distribution: Cambodia, Laos.

Specimens examined: LAOS. Bolikamxai: Thaphabat District, PKKNBCA, near Tad Xai Waterfall, along the trail in thick forest, $18^{\circ} 27^{\prime} 20.0^{\prime \prime} \mathrm{N}, 103^{\circ} 08^{\prime} 31.7^{\prime \prime} \mathrm{E}$, elev. $334 \mathrm{~m}, 12$ Nov 2017, Hyosig Won et al. 16233 (DGU); Thaphabat District, PKKNBCA, about $2 \mathrm{~km} \mathrm{NW}$ of the Tad Xai Waterfall, along the trail in thick forest, near the open rock area, $18^{\circ} 27^{\prime} 58.6^{\prime \prime} \mathrm{N}, 103^{\circ} 07^{\prime} 44.9^{\prime \prime} \mathrm{E}$, elev. 410 m, 12 Nov 2017, Hyosig Won et al. 16240 (DGU). Vientiane: Thoulakhom District, PKKNBCA, at restaurant near the river crossing over the Nam Mang River, downstream of the Nam Mang 3 Dam, near the Vang Hua Village, $18^{\circ} 21^{\prime} 07.4^{\prime \prime} \mathrm{N}, 102^{\circ} 48^{\prime} 50.6^{\prime \prime} \mathrm{E}$, elev. 748 m, 10 Nov 2017, Hyosig Won et al. 16162 (DGU, FOF, $\mathrm{KB})$. 

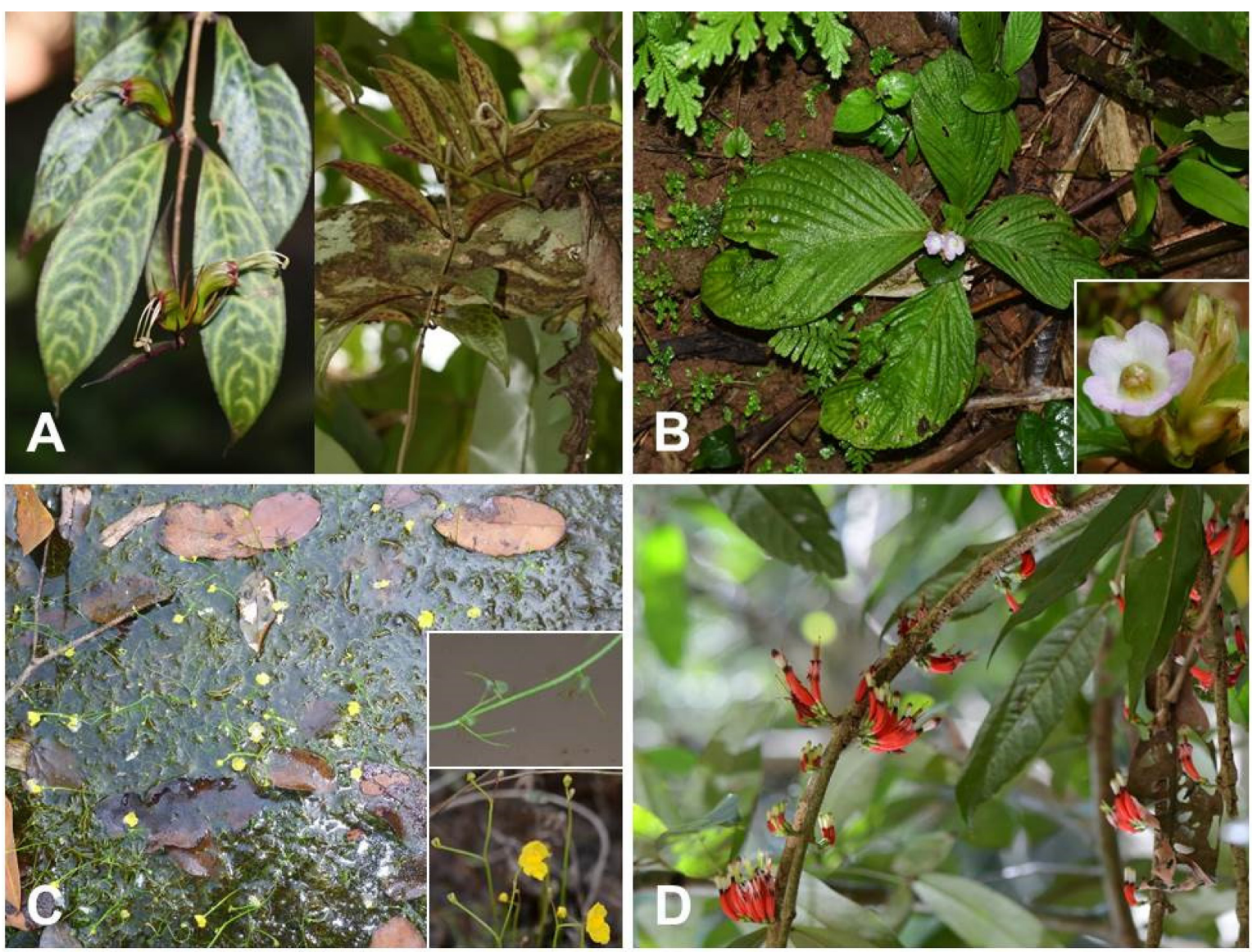

Fig. 3. New record of flowering plants for the flora of Laos (2). A. Aeschynanthus cambodiensis D.J. Middleton (Gesneriaceae). B. Tetraphyllum roseum Stapf (Gesneriaceae). C. Utricularia gibba L. (Lentibulariaceae). D. Macrosolen brandisianus (Kurz) Tiegh. (Loranthaceae).

6. Tetraphyllum roseum Stapf, J. Linn. Soc., Bot. 32: 524, 1896. (Fig. 3B).

Tetraphyllum spp. are perennial herbaceous plants and characterized by its four leaves in a whorl on top of stem (Möller et al., 2017; Weber et al., 2020). So far three species, T. bengalensis C. B. Clarke, T. confertiflorum (Drake) B. L. Burtt, and T. roseum, have been recognized in the world, and this is the first time Tetraphyllum is reported for the flora of Laos. Tetraphyllum roseum lives on vertical earth bank in partly shaded area and flowers in July. Like Didymocarpus spp., it develops much smaller and hairy leaves before the start of the dry season and the larger leaves are dried and fall off over the dry season. The larger leaves develop with the start of the rainy season.

Distribution: Malaysia, Laos, Thailand.

Specimens examined: LAOS. Vientiane: Thoulakhom District, PKKNBCA, along the old trail toward Vang Hua village, north of Ban Phonemuang, on vertical slope, $18^{\circ} 22^{\prime} 08.0^{\prime \prime} \mathrm{N}, 102^{\circ} 42^{\prime} 12.4^{\prime \prime E}$, elev. 235 m, 22 Jul 2017, Hyosig
Won et al. 16105 (DGU); Thoulakhom District, PKKNBCA, along the stream leading to the Nam Pot IDP reservior, flowing from PKKNBCA, along the old trail, north of Ban Phonemuang on steep earth surface along the stream, $18^{\circ} 22^{\prime} 10.0^{\prime \prime} \mathrm{N}, 102^{\circ} 42^{\prime} 15.6^{\prime \prime}$, elev. $252 \mathrm{~m}, 10$ Nov 2017, Hyosig Won et al. 16154 (DGU, FOF, KB).

\section{Lentibulariaceae}

7. Utricularia gibba L., Sp. Pl. 1: 18, 1753 (Fig. 3C).

Utricularia gibba shows pan-tropical distribution and has been reported widely, but no record from Laos, yet (Taylor, 1989; Parnell, 2011). Utricularia gibba is aquatic with filiform leaves and stems, characterized with a few, sparsely attached traps, unlike $U$. aurea with numerous traps. Utricularia gibba is more or less common in PKKNBCA, in small ponds, ditches, and marshes.

Distribution: Widespread, pan-tropical.

Specimens examined: LAOS. Bolikamxai: Thaphabat District, PKKNBCA, around Tad Leuk Waterfall, 18²3'42.0"N, 
10304'18.3"E, elev. 196 m, 15 Dec 2015, Hyosig Won et al. 13480 (DGU, FOF, KB); Thaphabat District, PKKNBCA, around Tad Leuk Waterfall, at the edge of the river, rock pool, $18^{\circ} 23^{\prime} 42.5^{\prime \prime} \mathrm{N}, 103^{\circ} 04^{\prime} 17.9^{\prime \prime}$, elev. 196 m, 26 Feb 2016, Hyosig Won et al. 13734 (DGU, FOF, KB); Thaphabat District, PKKNBCA, at the Nam Leuk Dam site, sip area at the southern end of the dam, open area, $18^{\circ} 26^{\prime} 08.2^{\prime \prime} \mathrm{N}, 102^{\circ} 56^{\prime} 41.8^{\prime \prime} \mathrm{E}$, elev. 403 m, 28 Feb 2016, Hyosig Won et al. 13794 (DGU, FOF, KB)

\section{Loranthaceae}

8. Macrosolen brandisianus (Kurz) Tiegh., Bull. Soc. Bot. France 42: 442, 1895. Loranthus brandisianus Kurz, J. Asiat. Soc. Bengal, Pt. 2, Nat. Hist. 40: 63, 1871 (Fig. 3D).

Macrosolen spp. are parasitic shrubs (Barlow, 2002) and three species, M. cochinchinensis (Lour.) Tiegh., M. lowii (King) Tregn., and M. tricolor (Lecomte) Dans., have been reported for the flora of Laos (Newman et al., 2017-present). Macrosolen brandisianus is characterized by its lanceolate to narrowly ovate leaves and deep red corolla tube with black band at the neck.

Distribution: Laos, Myanmar, Thailand.

Specimens examined: LAOS. Vientiane: Thoulakhom District, PKKNBCA, along the stream leading to the Nam Pot IDP reservior, flowing from PKKNBCA, along the old trail, north of Ban Phonemuang along the rocky stream, $18^{\circ} 22^{\prime} 06.1^{\prime \prime N}, 102^{\circ} 42^{\prime} 08.5^{\prime \prime E}$, elev. 225 m, 4 Jun 2017, Hyosig Won et al. 15767 (DGU, FOF, KB)

\section{Malvaceae}

9. Decaschistia siamensis Craib, Bull. Misc. Inform. Kew 1912: 146, 1912 (Fig. 4A).

Phuphathanaphong (1999) recognized three Decaschistia, D. parviflora Kurz, D. intermedia Craib, and D. siamensis, for the flora of Thailand. Decaschistia parviflora and D. intermedia have also been reported for Cambodia and Laos, respectively, while $D$. siamensis is endemic to Thailand. We collected $D$. siamensis in three different localities in PKKNBCA - near Vang Hua village, at Tad Leuk and Tad Xai Waterfalls. It is usually
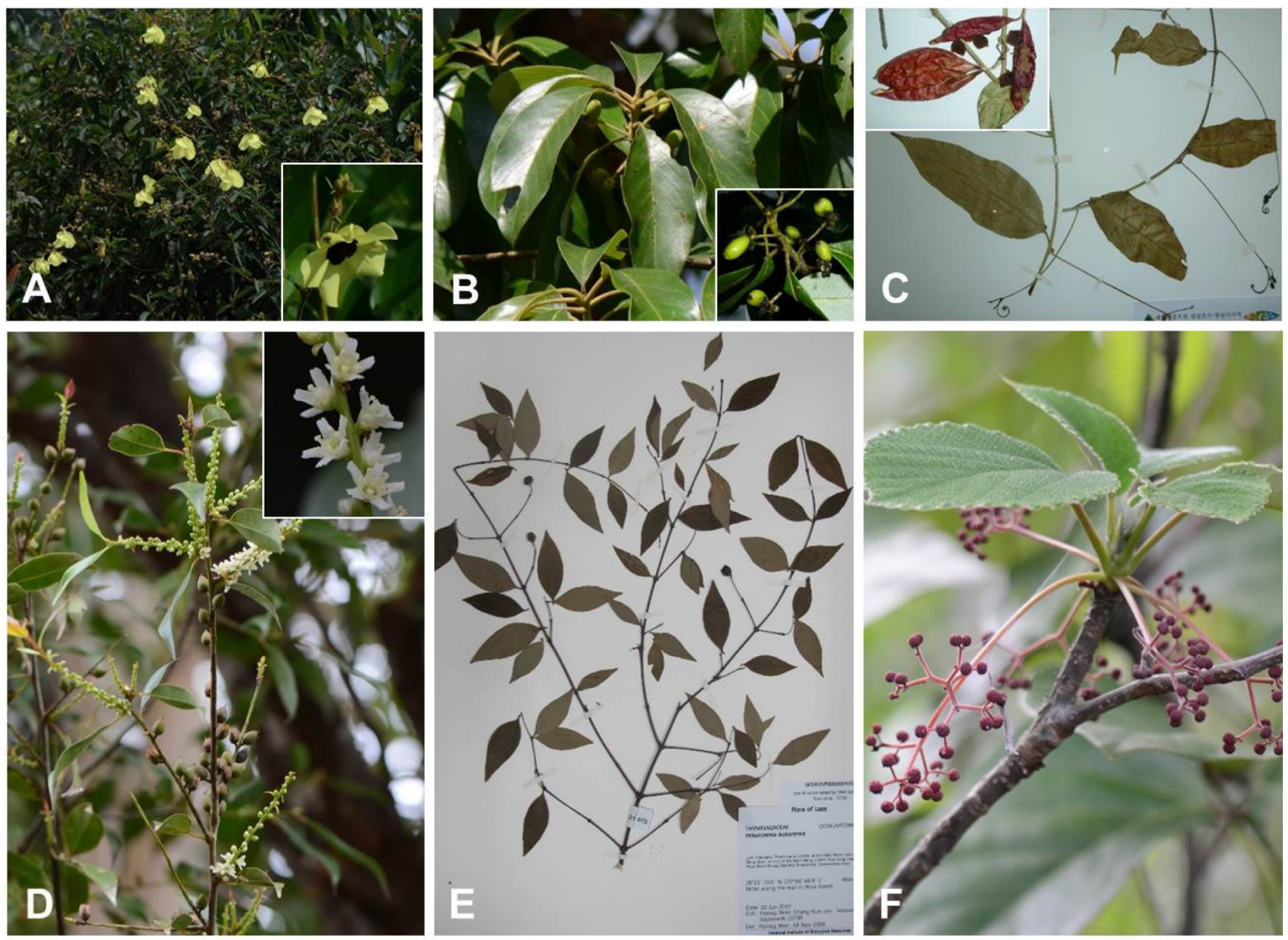

Fig. 4. New record of flowering plants for the flora of Laos (3). A. Decaschistia siamensis Craib (Malvaceae). B. Nyssa yunnanensis W. Q. Yin ex H. N. Qin \& Phengklai (Nyssaceae). C. Adenia penangiana (Wall. ex G. Don) W. J. de Wilde var. penangiana (Passifloraceae). D. Pentaphylax euryoides Gardner \& Champ. (Pentaphylacaceae). E. Wikstroemia bokorensis E. Oguri \& Tagane (Thymelaeaceae). F. Debregeasia wallichiana (Wedd.) Wedd. (Urticaceae). 
distributed in dry places on rock plateau with fairly open ground.

Distribution: Laos, Thailand.

Specimens examined: LAOS. Bolikamxai: Thaphabat District, PKKNBCA, at Tad Xai Waterfall, open, flat rock area, about $500 \mathrm{~m}$ NNE of the Tad Xai Waterfall, $18^{\circ} 27^{\prime} 33.6^{\prime \prime} \mathrm{N}$, 10308'35.0"E, elev. 369 m, 25 Feb 2016, Hyosig Won et al. 13697 (DGU, FOF, KB); Thaphabat District, PKKNBCA, at Tad Xai Waterfall, along the trail to the waterfall, about $200 \mathrm{~m}$ south of the waterfall, $18^{\circ} 27^{\prime} 09.6^{\prime \prime} \mathrm{N}, 103^{\circ} 08^{\prime} 32.0^{\prime \prime} \mathrm{E}$, elev. 320 m, 23 Aug 2016, Hyosig Won et al. 15482 (DGU, FOF, $\mathrm{KB}$ ); Thaphabat District, PKKNBCA, along the stream to the Tad Phaxet Waterfall, near the Tad Phaxet, open flat rock area, $18^{\circ} 30^{\prime} 02.0^{\prime \prime} \mathrm{N}, 102^{\circ} 57^{\prime} 45.4^{\prime \prime} \mathrm{E}$, elev. $608 \mathrm{~m}, 11$ Nov 2017, Hyosig Won et al. 16196 (DGU, FOF, KB). Vientiane: Thoulakhom District, PKKNBCA, near the river crossing over the Nam Mang River, downstream of the Nam Mang 3 Dam, near the Vang Hua Village, forest near the river, $18^{\circ} 21^{\prime} 05.2^{\prime \prime} \mathrm{N}$, 102 48'55.1"E, elev. 729 m, 20 Aug 2016, Hyosig Won et al. 15195 (DGU, FOF, KB).

\section{Nyssaceae}

10. Nyssa yunnanensis W. Q. Yin ex H. N. Qin \& Phengklai, Fl. China 13: 303, 2007 (Fig. 4B).

Nyssa species are dioecious trees with drupe. So far only $N$. javanica (Blume) Wangerin has been reported for Laos (Newman et al., 2017-present). We have made two collections of Nyssa from PKKNBCA, one with glabrous branchlets, pedicels and leaf abaxially side (Won et al. 16456, collected on $26 \mathrm{Jul} 2018$ ), the other with densely pilose ones (Won et al. 15673). Based on Qin and Phengklai (2007), the former matches well with the key characters of $N$. javanica, while the latter with $N$. yunnanensis.

Distribution: China, Laos.

Specimens examined: LAOS. Vientiane: Thoulakhom District, PKKNBCA, at the thick forest east of the Nam Mang River, at east of the Nam Mang 3 Dam, near Vang Hua village, along the trail in thick forest, $18^{\circ} 21^{\prime} 27.6^{\prime \prime} \mathrm{N}, 102^{\circ} 48^{\prime} 27.3^{\prime \prime} \mathrm{E}$, elev. 761 m, 2 Jun 2017, Hyosig Won et al. 15673 (DGU, FOF, $\mathrm{KB})$.

\section{Passifloraceae}

11. Adenia penangiana (Wall. ex G. Don) W. J. de Wilde var. penangiana, Blumea 15: 266, 1968. Passiflora penangiana Wall. \& G. Don, Gen. Hist. 3: 55, 1834 (Fig. 4C). Adenia penangiana (incl. A. nicobarica (Kurz.) Ridl.) is distributed in Andaman and Nicobar Islands, Peninsular Thailand, and also in Sumatra and Peninsular Malaysia (de Wilde and Duyfjes, 2010). Two varieties, var. penangiana and var. parvifolia (Gagnep.) W.J. de Wilde, are recognized for Thailand, where var. parvifolia has sometimes lanceolate-linear leaves, while var. penangiana has ovate-elliptic to lanceolate leaves. Current collections from PKKNBCA have leaves matching with var. penangiana. Although other Adenia species, such as A. viridiflora Craib (incl. A. pierrei Gagnep.), $A$. heterophylla (Blume) Koord. (incl. A. chevalieri Gagnep. and A. parviflora (Blanco) G. Cusset), A. cardiophylla (Mast.) Engl., and A. pinnatisecta (Craib) Craib have also been reported for Laos (Newman et al. 2017-present; de Wilde and Duyfjes, 2010), but A. penangiana is distinct from other Adenia by its unlobed and elliptic leaves.

Distribution: Laos, Malaysia, Sumatra, Thailand.

Specimens examined: LAOS. Bolikamxai: Thaphabat District, PKKNBCA, along the road to the north part of the Nam Leuk Reservior, near Tad Phaxet, 18 31'34.3"N, $102^{\circ} 56^{\prime} 00.5^{\prime \prime E}$, elev. $451 \mathrm{~m}$, 5 Jun 2017, Hyosig Won et al. 15801 (DGU, FOF, KB); Thaphabat District, PKKNBCA, along the road to the water duct, branching from the road to the Nam Leuk Dam, in thickets, roadside, $18^{\circ} 28^{\prime} 02.2^{\prime \prime} \mathrm{N}$, 102 58'24.3"E, elev. 434 m, 20 Jul 2017, Hyosig Won et al. 16051 (DGU, FOF, KB). Vientiane: Thoulakhom District, PKKNBCA, at the thick forest east of the Nam Mang River, at east of the Nam Mang 3 Dam, near Vang Hua village along the trail in thick forest, $18^{\circ} 21^{\prime} 20.7^{\prime \prime} \mathrm{N}, 102^{\circ} 48^{\prime} 25.7^{\prime \prime} \mathrm{E}$, elev. 775 m, 1 Nov 2016, Chang-Kun Lim \& Veosavanh Saysavanh Lim708 (DGU, FOF, KB).

\section{Pentaphylacaceae}

12. Pentaphylax euryoides Gardner \& Champ., Hooker's J. Bot. Kew Gard. Misc. 1: 245, 1849 (Fig. 4D).

Pentaphylax is a monotypic genus with 5-merous flowers. Its flower has five petals, sepals, and stamens, and pistils are 5-celled. Stamens are basifixed and dehiscing with apical pores. It is distributed on fairly open rock area near Tad Phaxet Waterfall.

Distribution: China, Indonesia, Laos, Malaysia, Vietnam.

Specimens examined: LAOS. Bolikamxai: Thaphabat District, PKKNBCA, along the road to the north part of the Nam Leuk Reservior, near Tad Phaxet, open flat rock area, along the stream to $\mathrm{Tad}$ Phaxet waterfall, 18 $30^{\prime} 10.1^{\prime \prime} \mathrm{N}$, $102^{\circ} 57^{\prime} 57.5$ "E, elev. 624 m, 27 Feb 2016, Hyosig Won et al. 13766 (DGU, FOF, KB).

\section{Thymelaeaceae}

13. Wikstroemia bokorensis E. Oguri \& Tagane, Phytotaxa 317: 281, 2017 (Fig. 4E).

Oguri et al. (2017) described W. bokorensis based on the 
specimens collected from Bokor National Park, Kampot Province, Cambodia. Recently, W. bolovenensis Tagane \& Soulad. was described from the specimens collected from Bolaven Plateau, Paksong District, Champasak Province of Laos (Tagane et al., 2020a). Tagane et al. (2020a) distinguished the two species based on the inflorescence type, length of peduncle, and their phenology: W. bokorensis has umbellate or rarely very shortly racemose inflorescence with 3-6 flowers, while $W$. bolovenensis has racemose inflorescence with 10-14 flowers. The length of peduncle is $1.2-3 \mathrm{~cm}$ long and slender for $W$. bokorensis, while $W$. bolovenensis is $0.5-1 \mathrm{~cm}$ long and slightly flattened. Wikstroemia bokorensis flowers in May with immature fruits, while $W$. bolovenensis flowers and fruits maturing in December. The collection from PKKNBCA (Won et al. 15730) has typical morphological characteristics of $W$. bokorensis-umbellate inflorescence with slender peduncle 1.5-2 cm long, a few number of flowers (fruits), and mature fruits in June. It is unusual to discover $W$. bokorensis in PKKNBCA, which is more than $510 \mathrm{~km}$ north of Bokor National Park, Cambodia. Overall morphology and molecular data (unpublished data) confirms its identity in PKKNBCA. Additional surveys on the area will be necessary to collect flowering material and to assess its conservation status.

Distribution: Cambodia, Laos.

Specimens examined: LAOS. Vientiane: Thoulakhom District, PKKNBCA, at the thick forest east of the Nam Mang River, at east of the Nam Mang 3 Dam, near Vang Hua village, along the trail in thick forest, $18^{\circ} 21^{\prime} 10.5^{\prime \prime} \mathrm{N}$, 102 48'48.9"E, elev. 748 m, 3 Jun 2017, Hyosig Won et al. 15730 (DGU, FOF, KB).

\section{Urticaceae}

14. Debregeasia wallichiana (Wedd.) Wedd., Ann. Mus. Hist. Nat., Paris 9: 464, 1956-7. Debregeasia wallichiana Wedd., Arch. Mus. Hist. Nat. viii. 464, 1855-6 (Fig. 4F).

Debregeasia spp. are shrubs or small trees, and there are about six species mainly in tropics and subtropics of E Asia (Chen et al., 2003). Debregeasia wallichiana is characterized by its broadly ovate to orbicular leaves with white tomentose abaxial surface and dichotomously branching inflorescences longer than $5 \mathrm{~cm}$.

Distribution: Bangladesh, Bhutan, Cambodia, India, Myanmar, Laos, Sikkim, Sri Lanka, Thailand

Specimens examined: LAOS. Vientiane: Thoulakhom District, PKKNBCA, at the thick forest east of the Nam Mang River, at east of the Nam Mang 3 Dam, near Vang Hua village, along the trail in thick forest, $18^{\circ} 21^{\prime} 30.1^{\prime \prime N}, 102^{\circ} 48^{\prime} 22.1^{\prime \prime E}$, elev. 765 m, 2 Jun 2017, Hyosig Won et al. 15675 (DGU, FOF, KB).

\section{Taxa newly recorded from PKKNBCA, previously reported for the flora of Laos}

\section{Asteraceae}

1. Strobocalyx arborea (Buch.-Ham.) Sch. Bip., Jahresber. Pollichia 18-19: 171, 1861. Vernonia arborea Buch.-Ham., Trans. Linn. Soc. London 14: 218, 1824 (Fig. 5A).

Strobocalyx arborea is a large tree species of Asteraceae, distributed in SE Asia. Based on the DNA sequence data and morphological data, Robinson et al. (2008) transferred seven species formerly placed in Vernonia to Strobocalyx. The collection was made from a tree ca. $20 \mathrm{~m}$ tall and D.B.H. of ca. $30 \mathrm{~cm}$.

Distribution: Bangladesh, China, India, Indonesia, Laos, Malaysia, Myanmar, Philippines, Thailand, Vietnam,

Specimen examined: LAOS. Bolikamxai: Thaphabat District, PKKNBCA, along the road to Nam Leuk Dam, branched from the road between Ban Tha and Muang Hom, $18^{\circ} 28^{\prime} 07.9^{\prime \prime} \mathrm{N}, 103^{\circ} 01^{\prime} 26.1^{\prime \prime} \mathrm{E}$, elev. $568 \mathrm{~m}, 11$ Nov 2017, Hyosig Won et al. 16211 (DGU, KB).

\section{Euphorbiaceae}

2. Croton poomae Esser, Thai Forest Bull., Bot. 30: 1, 2002 (Fig. 5B).

Croton poomae is a tree to ca. $10 \mathrm{~m}$ tall. Esser (2002) recognized $C$. poomae for the flora of Thailand. Specimens (incl. Type) of $C$. poomae were collected from Phu Wua Wildlife Sanctuary, Bungkhla, Nong Khai, Thailand, which is near the border with Laos, close to the Mekong River. Also, Newman et al. (2017-present) reported its presence at Nam Kading NPA from the collection made by Tagane et al. Croton poomae is characterized by its long, narrowly ovate leaves with 13-16 pairs of side veins, acute-acuminate leaf apex, completely silvery-pubescent leaf abaxial surface, globose schizocarp 15-17 mm long, and brownish pubescent and smooth schizocarp surface.

Distribution: Laos, Thailand.

Specimen examined: LAOS. Bolikamxai: Thaphabat District, PKKNBCA, at the north part of the Nam Leuk Reservior, near Tad Phaxet, at thick forest along the cliff of the road, 18 $30^{\prime} 23.7^{\prime \prime} \mathrm{N}, 102^{\circ} 56^{\prime} 12.5^{\prime \prime} \mathrm{E}$, elev. $417 \mathrm{~m}, 22$ Aug 2016, Hyosig Won et al. 15383 (DGU, KB); Thaphabat District, PKKNBCA, along the road to the water duct, branching from the road to the Nam Leuk Dam, in thickets, roadside, $18^{\circ} 29^{\prime} 54.7^{\prime \prime N}, 102^{\circ} 57^{\prime} 42.1$ "E, elev. 596 m, 20 Jul 2017, Hyosig Won et al. 16039 (DGU, KB); Thaphabat District, PKKNBCA, along the road to the water duct, branching from the road to the Nam Leuk Dam, in thickets, roadside, $18^{\circ} 27^{\prime} 58.0^{\prime \prime} \mathrm{N}$, 

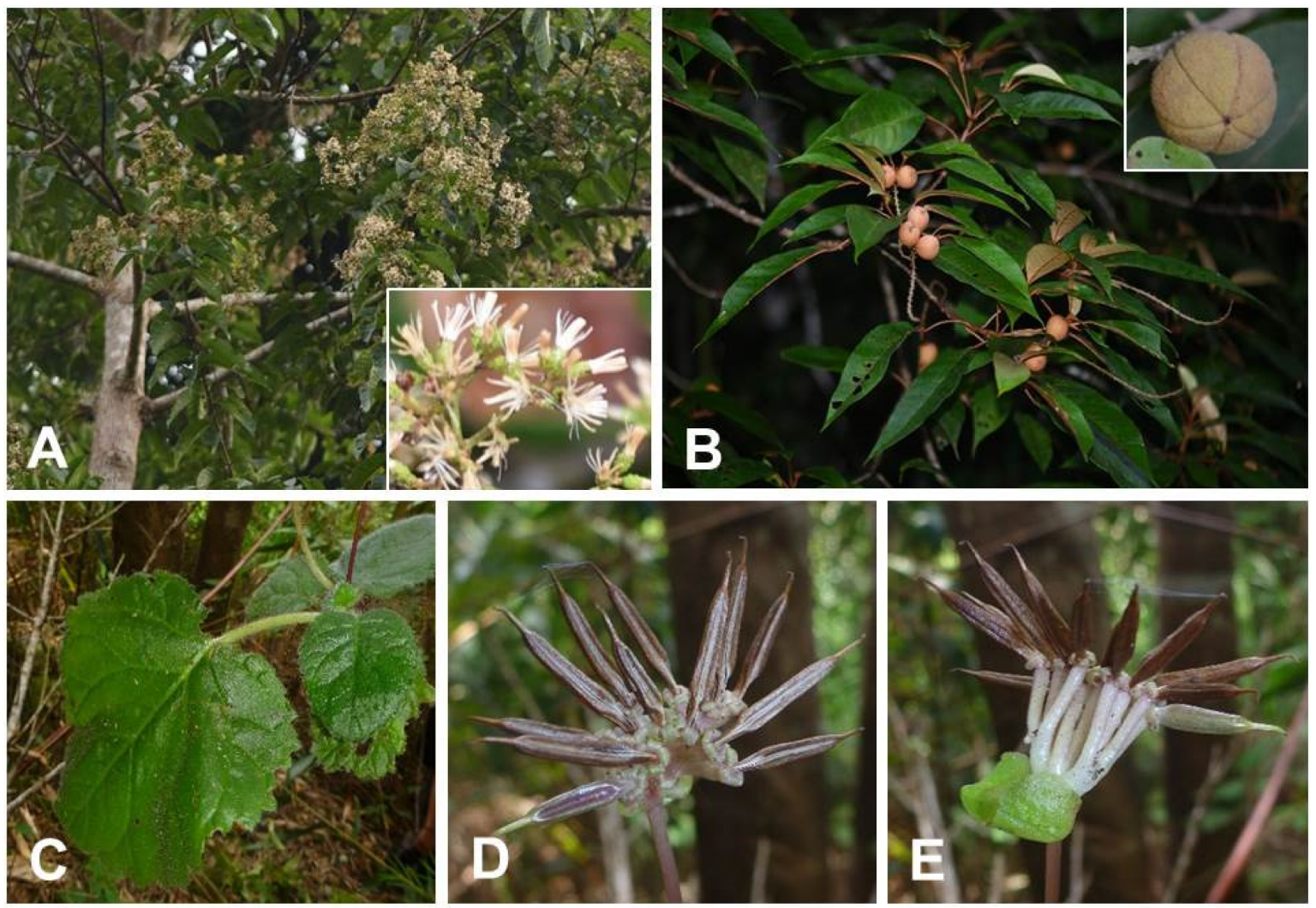

Fig. 5. New record of flowering plants from PKKNBCA. A. Strobocalyx arborea (Buch.-Ham.) Sch. Bip. (Asteraceae). B. Croton poomae Esser (Euphorbiaceae). C-E. Beccarinda tonkinensis (Pellegr.) B. L. Burtt (Gesneriaceae).

102 58'48.5"E, elev. 469 m, 20 Jul 2017, Hyosig Won et al. 16054 (DGU, KB). Vientiane Province: Thoulakhom District, PKKNBCA, along the old trail to Vang Hua village, $18^{\circ} 22^{\prime} 08.1^{\prime \prime N}, 102^{\circ} 42^{\prime} 11.7^{\prime \prime E}$, elev. 230 m, 26 Jul 2018, Hyosig Won et al. 16450 (DGU, KB).

\section{Gesneriaceae}

3. Beccarinda tonkinensis (Pellegr.) B. L. Burtt, Notes Roy. Bot. Gard. Edinburgh 22: 64, 1965. Slackia tonkinensis Pellegr., Bull. Soc. Bot. France 73: 428, 1926 (Fig. 5C-E).

Beccarinda tonkinensis is a perennial herb with umbel-like inflorescence, distributed from China to India (Gammi et al., 2020). Newman et al. (2017-present) reported its presence in Khammouan District. We found a small population on rock surface in a shaded forest of PKKNBCA.

Distribution: China, India, Laos, Vietnam.

Specimen examined: Laos. Vientiane Province: Thoulakhom District, PKKNBCA, along the trail from the army camp (near the lake) to Phou Xang, about $4 \mathrm{~km}$ north from the camp, on rock surface in shaded forest, $18^{\circ} 25^{\prime} 29.3^{\prime \prime} \mathrm{N}, 102^{\circ} 45^{\prime} 49.0^{\prime \prime} \mathrm{E}$, elev. 1,112 m, 8 Sep 2019, Hyosig Won et al. 17056 (DGU, KB).
4. Didymocarpus albiflorus Souvann. \& Phonepaseuth, Taiwania 65: 109, 2020 (Fig. 6A).

Souvannakhoummane and Phonepaseuth (2020) reported $D$. albiflorus as a new endemic species of Laos, collected from Darn Sinxay Temple area, Naxaythong District, Vientiane Capital. The type locality is west of Vientiane, and we found the same species also in PKKNBCA, located east of Vientiane.

\section{Distribution: Laos.}

Specimen examined: LAOS. Vientiane: Thoulakhom District, PKKNBCA, near the waterfall in the valley, along the old PKKNBCA trail toward the Vang Hua village, north of Ban Phonemuang, on steep rock surface, $18^{\circ} 22$ '21.6"N, 102'42'26.1"E, elev. 281 m, 22 Jul 2017, Hyosig Won et al. 16129 (DGU, KB); Thoulakhom District, PKKNBCA, near the waterfall in the valley, along the old PKKNBCA trail toward the Vang Hua village, north of Ban Phonemuang, on rock boulder, $18^{\circ} 22^{\prime} 20.9^{\prime \prime} \mathrm{N}, 102^{\circ} 42^{\prime} 25.1^{\prime \prime E}$, elev. $274 \mathrm{~m}, 10$ Nov 2017, Hyosig Won et al. 16150 (DGU); Thoulakhom District, PKKNBCA, along the old trail to Vang Hua village, on top and on the vertical surface of boulder, along the stream, $18^{\circ} 22^{\prime} 48.7^{\prime \prime} \mathrm{N}, \quad 102^{\circ} 44^{\prime}$ 00.8"E, elev. 706 m, 28 Jul 2018, 

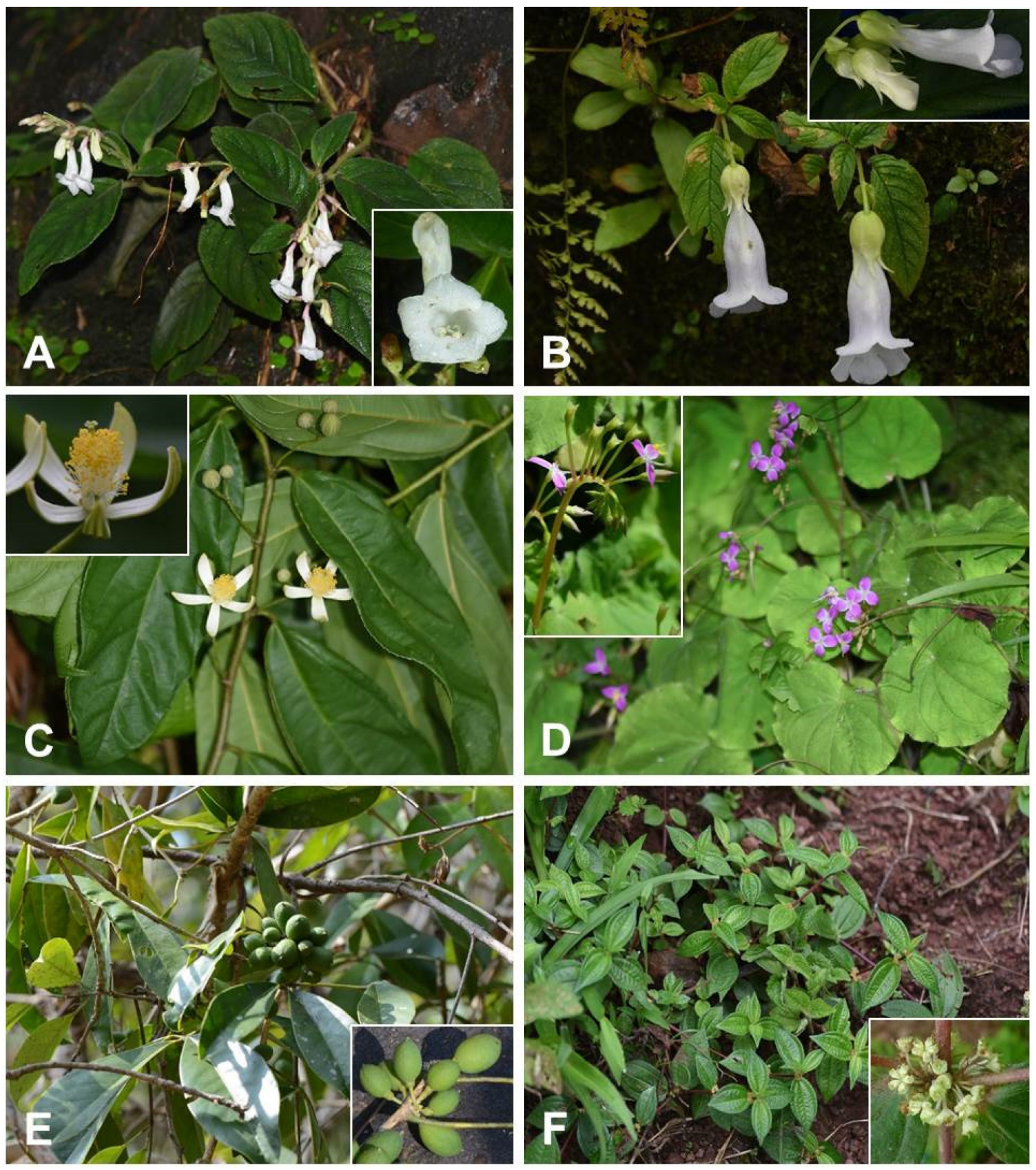

Fig. 6. New record of flowering plants from PKKNBCA A. Didymocarpus albiflorus Souvann. \& Phonepaseuth (Gesneriaceae). B. Henckelia anachoreta (Hance) D.J. Middleton (Gesneriaceae). C. Grewia laevigata Vahl (Malvaceae). D. Sonerila souvannii Phonep. \& Soulad. (Melastomataceae). E. Luvunga scandens (Roxb.) Buch.-Ham. ex Wight \& Arn. (Rutaceae). F. Gonostegia hirta (Blume) Miq. (Urticaceae).

Hyosig Won et al. 16487 (DGU); Thoulakhom District, PKKNBCA, along the old trail to Vang Hua village, on top and on the vertical surface of boulder, $18^{\circ} 22^{\prime} 39.6^{\prime \prime} \mathrm{N}$, 102 43'24.3"E, elev. 591 m, 28 Jul 2018, Hyosig Won et al. 16489 (DGU).
5. Henckelia anachoreta (Hance) D.J. Middleton, Taxon 60: 774, 2011. Chirita anachoreta Hance, Ann. Sci. Nat., Bot. sér. 5, 5: 231, 1866 (Fig. 6B).

Henckelia anachoreta shows wide distribution from southern China, India (Sikkim), Laos, Myanmar, northern Thailand and northern Vietnam (Weber et al., 2011). It grows on moist rock 
surfaces. Yang, L. et al. (2020) examined one collection from Nakai Nam Theun NPA of Khammouan Province (M. F. Newman et al. LAO 385 [E]).

Distribution: China, India, Laos, Myanmar, Thailand, Vietnam.

Specimen examined: LAOS. Vientiane Province: Thoulakhom District, PKKNBCA, along the trail from the army camp (near the lake) to Phou Xang, about $4 \mathrm{~km}$ north from the camp, on rock surface in shaded forest, $18^{\circ} 25^{\prime} 27.7^{\prime \prime} \mathrm{N}$, $102^{\circ} 45^{\prime} 50.4^{\prime \prime E}$, elev. 1,087 m, 8 Sep 2019, Hyosig Won et al. 17055 (DGU); Thoulakhom District, PKKNBCA, along the trail from the cow farm near the base of rim to Phu Xang to the army camp (near the lake), about $3 \mathrm{~km}$ north from the army camp, on a rock boulder, in shaded forest, $18^{\circ} 25^{\prime} 28.3^{\prime \prime} \mathrm{N}$, 102 45'49.0"E, elev. 1,092 m, 9 Sep 2019, Hyosig Won et al. 17084 (DGU).

\section{Malvaceae}

6. Grewia laevigata Vahl, Symb. Bot. (Vahl) 1: 34, 1790 (Fig. 6C).

Chung (2006) distinguished $G$. laevigata from the other Grewia as a scandent shrub, having twigs and peduncles glabrous or sparsely hairy, leaves elliptic, oblong, lanceolate or ovate, flower buds oblong, narrowly ellipsoid or narrowly ovoid.

Distribution: India, Laos, Malaysia, Philippines, Thailand, Vietnam.

Specimen examined: LAOS. Vientiane Province: Thoulakhom District, PKKNBCA, near the Dansavanh Nam Ngum Lake Resort, 18²5'25.4"N, 102³8'54.2"E, elev. 284 m, 25 Jul 2018, Hyosig Won et al. 16442 (DGU, KB).

\section{Melastomataceae}

7. Sonerila souvannii Phonep. \& Soulad., Eur. J. Taxon. 755: 141, 2021 (Fig. 6D).

Sonerila souvannii is an acaulescent herb characterized by its cordate leaves, glabrous inflorescences, petals and capsules, and cylindrical rhizome (Phonepaseuth et al., 2021a). We found a few populations of $S$. souvannii near the Tad Xai waterfall. Likewise D. albiflora (Gesneriaceae), S. souvannii was collected from Darn Sinxay Temple area, Naxaythong District, Vientiane Capital (Phonepaseuth et al., 2021a). The presence of both $D$. albiflora and S. souvannii suggests close floristic affinity between PKKNBCA and Darn Sinxay Temple area, Naxaythong District, located west of Vientiane Capital.

Distribution: Laos.

Specimen examined: LAOS. Bolikamxai: Thaphabat District, PKKNBCA, at Tad Xai waterfall, along a trail to the waterfall, about $200 \mathrm{~m}$ south of the waterfall, $18^{\circ} 27^{\prime} 09.6^{\prime \prime} \mathrm{N}$, 10308'32.0"E, elev. 320 m, 23 Aug 2016, Hyosig Won et al. 15483 (DGU, KB); Thaphabat District, PKKNBCA, near Tad Xai waterfall, at rock boulder along the stream, 18 $27^{\prime} 12.1^{\prime \prime} \mathrm{N}$, 10308'32.3"E, elev. 307 m, 12 Nov 2017, Hyosig Won et al. 16232 (DGU); Thaphabat District, PKKNBCA, at Tad Xai waterfall, along a trail to the waterfall, about $200 \mathrm{~m}$ south of the waterfall, under rock boulder, $18^{\circ} 27^{\prime} 09.6^{\prime \prime} \mathrm{N}, 103^{\circ} 08^{\prime} 32.0^{\prime \prime} \mathrm{E}$, elev. 320 m, 10 Sep 2019, Hyosig Won et al. 17102 (DGU).

\section{Rutaceae}

8. Luvunga scandens (Roxb.) Buch.-Ham. ex Wight \& Arn., Ill. Ind. Bot. 1: 108, 1838. Limonia scandens Roxb., Fl. Ind. ii. 380,1832 (Fig. 6E).

Luvunga scandens is a woody climber with 3-foliate leaves, usually distributed along riverbanks and valleys. Newman et al. (2017-present) enlisted L. scandens for the flora of Laos, without voucher information. Here we are providing a voucher information collected from PKKNBCA.

Distribution: Cambodia, China, India, Laos, Malaysia, Thailand, Vietnam.

Specimens examined: LAOS. Bolikamxai: Thaphabat District, PKKNBCA, at Tad Xang Waterfall, upstream of Tad Leuk waterfall along the Tad Leuk river, around the open rock river basin, $18^{\circ} 24^{\prime} 04.8^{\prime \prime} \mathrm{N}, 103^{\circ} 02^{\prime} 58.4^{\prime \prime} \mathrm{E}$, elev. $228 \mathrm{~m}, 26 \mathrm{Feb}$ 2016, Hyosig Won et al. 13715 (DGU, KB).

\section{Urticaceae}

9. Gonostegia hirta (Blume) Miq., Ann. Mus. Bot. LugdunoBatavi 4: 303, 1869. Urtica hirta Blume, Bijdr. Fl. Ned. Ind. 10: 495, 1826. Pouzolzia hirta (Blume) Hassk., Cat. Hort. Bot. Bogor (Hasskarl) 80, 1844 (Fig. 6F).

Gonostegia hirta is a prostrate herb or subshrub, with ovate or elliptic leaves attached oppositely. It is found on open grassland near the rim of Phu Xang of PKKNBCA.

Distribution: Cambodia, China, India, Laos, Malaysia, Thailand, Vietnam.

Specimens examined: LAOS. Vientiane Province: Thoulakhom District, PKKNBCA, along the south ridge leading to the rim of Phu Xang, open grassy slopes, $18^{\circ} 26^{\prime} 32.0^{\prime \prime} \mathrm{N}, 102^{\circ} 44^{\prime} 56.8^{\prime \prime} \mathrm{E}$, elev. 1,475 m, 9 Sep 2019, Hyosig Won et al. 17065 (DGU, KB).

ORCID: Chang-Kun LIM https://orcid.org/0000-0002-1799-7818; Kyoung-Eun LEE https://orcid.org/0000-0002-8024-6304; HyunSung CHO https://orcid.org/0000-0002-7137-6836; Hyosig WON https://orcid.org/0000-0001-7619-943X 


\section{Acknowledgments}

Authors thank the anonymous reviewers for their helpful comments on this manuscript. We also thank Juhyun Kim, Sojeong Lee, and Khulan Sharavdorj of Daegu University, and local forestry officers of Lao PDR for their help with field work. We are grateful to the herbarium staffs at BKF, BK, and QBG for their help with herbarium work. This work was supported by a fund from the National Institute of Biological Resources (NIBR), entitled "Survey and Classification of Biological Resources of Mekong Area" (NIBR202006203).

\section{Conflict of Interest}

The authors declare that there are no conflicts of interest.

\section{Literature Cited}

Aubréville, A. and J.-F. Leroy. 1960 to present. Flore du Cambodge, du Laos et du Vietnam. Museum National D’histoire Naturelle, Paris. (in French)

Barlow, B. 2002. Loranthaceae. In Flora of Thailand, Vol. 7, Part 4. Spermatophyte: Buddlejaceae to Viscaceae. Santisuk, T. and K. Larsen (eds.), The Forest Herbarium, National Park, Wildlife and Plant Conservation Department, Bangkok. Pp. 665706 .

Chayamarit, K. 1991. Capparaceae. In Flora of Thailand, Vol. 5, Part 3. Scrophulariaceae. Smitinand, T. and K. Larsen (eds.), The Forest Herbarium, National Park, Wildlife and Plant Conservation Department, Bangkok. Pp. 241-271.

Chen, J., I. Friis and C. M. Wilmot-Dear. 2003. Debregeasia. In Flora of China, Vol. 5. Ulmaceae through Basellaceae. Wu, Z. Y., P. H. Raven and D. Y. Hong (eds.), Science Press, Beijing and Missouri Botanical Garden Press, St. Louis, MO. Pp. 185187.

Chung, R. C. K. 2006. Revision of Grewia (Malvaceae - Grewioideae) in Peninsular Malaysia and Borneo. Edinburgh Journal of Botany 62: 1-27.

De Wilde, W. J. J. O. and B. E. E. Duyfjes. 2010. Adenia. In Flora of Thailand, Vol. 10, Part 2. Celastraceae, Hernandiaceae, Leeaceae, Mastixiaceae, Passifloraceae, Verbenaceae. Santisuk, T. and K. Larsen (eds.), The Forest Herbarium, National Park, Wildlife and Plant Conservation Department, Bangkok. Pp. 236-251.

Esser, H.-J. 2002. Croton poomae (Euphorbiaceae), a new species from Thailand. Thai Forest Bulletin 30: 1-6.

Fici, S. 2016. Studies on the genus Capparis L. (Capparaceae) in Lao PDR. Webbia 71: 169-175.
Fici, S., S. Bouamanivong and K. Souvannakhoummane. 2017. Studies on the genus Capparis L. (Capparaceae) in Lao PDR. II: A new species from Khammouan karst. Webbia 73: 5-7.

Fici, S., K. Souvannakhoummane, S. Lanorsavanh and V. Lamxay. 2020. Studies on the genus Capparis L. (Capparaceae) in Lao PDR. IV: A new species from the Khammouan Province. Phytotaxa 429: 73-79

Fici, S. and K. Souvannakhoummane. 2020. Studies on the genus Capparis L. (Capparaceae) in Lao PDR. V: A new species from limestones of the Luang Prabang Province. Adansonia 42: 113-118.

Gammi, L., D. Borah, M. Taram, H. Tag and A. A. Khapugin. 2020. Beccarinda tonkinensis (Gesneriaceae), a new record for India and its IUCN Red List status in India. Wulfenia 27: 139_ 144.

Hul, S. 2010. Two new species of Gentianaceae from Indo-China. Edinburgh Journal of Botany 67: 155-160.

Lanorsavanh, S. and P. Chantaranothai. 2013. Two new records of Argostemma Wall. (Rubiaceae) for Laos. Thai Journal of Botany $5: 21-25$.

Lanorsavanh, S. and P. Chantaranothai. 2019. Notes on the genus Argostemma (Rubiaceae) from Lao PDR. Thai Forest Bulletin (Botany) 47: 29-33.

Lanorsavanh, S., P. Chantaranothai and K. Souvannakhoummane. 2020. Six new species of Argostemma Wall. (Rubiaceae) from Laos. Nordic Journal of Botany 38: e02714.

Leong-Škorničková, J., O. Šída, S. Bouamanivong, K. Souvannakhoummane, and K. Phathavong. 2014. Three new ginger species (Zingiberaceae) from Laos. Blumea 59: 106-112.

Lim, C.-K., J. Kim, V. Saysavanh and H. Won. 2015. New records of flowering plants from Lao PDR. Korean Journal of Plant Taxonomy 46: 348-355.

Middleton, D. J. 2009. A revision of Aeschynanthus (Gesneriaceae) in Cambodia, Laos and Vietnam. Edinburgh Journal of Botany 66: 391-446.

Middleton, D. J. 2016. A revision of Aeschynanthus (Gesneriaceae) in Singapore and Peninsular Malaysia. Gardens' Bulletin Singapore 68: 1-63.

Möller, M., S. Nampy, A. P. Janeesha and A. Weber. 2017. The Gesneriaceae of India: Consequences of updated generic concepts and new family classification. Rheedea 27: 23-41.

Nagahama, A., S. Tagane, P. Souladeth, A. Sengthong and T. Yahara. 2019. Gentiana bolavenensis (Gentianaceae), a new species from Dong Hua Sao National Protected Area in Southern Laos. Thai Forest Bulletin (Botany) 47: 133-136.

Nanthavong, K. 2015. Plant biodiversity in Phou Khao Khouay National Biodiversity Conservation Area, Lao PDR. In Botanical Research in Tropical Asia Meeting, 2015 Dec 6-11, Vien- 
tiane, Lao PDR, No. 81633.

Newman, M. F. 2015. A new species of Zingiber (Zingiberaceae) from Lao P.D.R. Gardens' Bulletin Singapore 67: 123-127.

Newman, M., S. Ketphanh, B. Svengsuksa, P. Thomas, K. Sengdala, V. Lamxay and K. Armstrong. 2007. A Checklist of the Vascular Plants of Lao PDR. Royal Botanic Garden Edinburgh, $394 \mathrm{pp}$.

Newman, M., M. Pullan, S. Ketphanh, B. Svengsuksa, P. Thomas, K. Sengdala, V. Lamxay, and K. Armstrong. 2017-present. A checklist of the vascular plants of Lao PDR. Royal Botanic Garden Edinburgh, Edinburgh. Retrieved Sep. 20, 2021, available from: https://padme.rbge.org.uk/laos/

Oguri, E., S. Tagane, P. Chhang, H. Toyama, N. Murakami and T. Yahara. 2017. Flora of Bokor national park, Cambodia VI: A new species of Wikstroemia (Thymelaeaceae), $W$. bokorensis. Phytotaxa 317: 280-285.

Panyadee, P., W. Tanming and C. Maknoi. 2020. Plants without borders: New records of two presumed Thai endemic Gesneriaceae in Laos. Gardens' Bulletin Singapore 72: 285-290.

Parnell, J. A. N. 2011. Lentibulariaceae. In Flora of Thailand, Vol. 11, Part 1. Santisuk, T. and K. Larsen (eds.), The Forest Herbarium, National Park, Wildlife and Plant Conservation Department, Bangkok. Pp. 16-45.

Phonepaseuth, P., P. Souladeth, K. Souvannakhoummane, T. Vongthavone and S. Tagane. 2021a. Two new species of Sonerila Roxb. (Melastomataceae) from Laos. European Journal of Taxonomy 755: 136-148.

Phonepaseuth, P., K. Souvannakhoummane, S. Tagane, P. Souladeth, and T. Yahara. 2021b. A new species of Paraboea and a new species record of Middletonia (Gesneriaceae) from a limestone karst in Central Laos. Thai Forest Bulletin (Botany) 49: 135-141.

Phuphathanaphong, L. 1999. Decaschistia (Malvaceae) in Thailand. Thai Forest Bulletin (Botany) 27: 83-85.

Prosperi, J., V. Lamxay, F. Hallé, J.-M. Bompard, P. Blanc, B. R. Ramesh, N. Ayyappan and S. Cardinal. 2018. New records in the flora checklist of Laos, resulting from a survey of Phou Hin Poun National Biodiversity Conservation Area. Edinburgh Journal of Botany 75: 91-106.

Qin, H. and C. Phengklai. 2007 Nyssaceae. In Flora of China. Vol. 13. Clusiaceae through Araliaceae. Wu, Z. Y., P. H. Raven and D. Y. Hong (eds.), Science Press, Beijing and Missouri Botanical Garden Press, St. Louis, MO. Pp. 300-303.

Robinson, H., S. C. Keeley, J. J. Skvarla and R. Chan. 2008. Studies on the Gymnantheminae (Vernonieae: Asteraceae) III: Restoration of the genus Strobocalyx and the new genus Tarlmounia. Proceedings of the Biological Society of Washington 121: 19-33.
Rodda, M. and U. Meve. 2017. Ceropegia laotica (Apocynaceae, Asclepiadoideae): The first new species of Ceropegia described from Laos. Gardens' Bulletin Singapore 69: 285293.

Smitinand, T. and K. Larsen. 1970-present. Flora of Thailand. The Forest Herbarium, Bangkok.

Soukhavong, M., L. Yong, K. Nanthavong and J. Millet. 2013. Investigation on species composition of plant community at Tad Xai at Phou Khao Khouay National Park, Lao PDR. Our Nature 11: 1-10.

Souladeth, P., S. Tagane, M. F. Newman and A. Prajaksood. 2020. Two new species of Eriocaulon (Eriocaulaceae) from Laos. Kew Bulletin 75: 56.

Souladeth, P., S. Tagane, Y. Suyama, N. Ishii, A. Nagahama and K. Souvannakhoummane. 2021. Impatiens subfalcata (Balsaminaceae), a new species from Laos. Edinburgh Journal of Botany 78: 1-10.

Souladeth, P., S. Tagane and T. Yahara. 2019. Flora of Nam Kading National Protected Area V: Two new species of Camellia (Theaceae), C. namkadingensis and C. rosacea. Thai Forest Bulletin (Botany) 47: 82-90.

Souladeth, P., S. Tagane, M. Zhang, N. Okabe and T. Yahara. 2017. Flora of Nam Kading National Protected Area I: A new species of yellow-flowered Strobilanthes (Acanthaceae), S. namkadingensis. PhytoKeys 81: 11-17.

Souvannakhoummane, K., S. Fici, S. Lanorsavanh and V. Lamxay. 2018. Studies on the genus Capparis L. (Capparaceae) in Lao PDR. III: A new species from the deciduous forest of the Hin Nam No National Protected Area. Webbia 73: 175-177.

Souvannakhoummane, K. and P. Suksathan. 2015. Two new species of Impatiens (Balsaminaceae) from North of Lao PDR. Taiwania 60: 175-180.

Souvannakhoummane, K. and J. Leong-Škorničková. 2018. Eight new records of Zingiber Mill. (Zingiberaceae) for the flora of Lao P.D.R. Edinburgh Journal of Botany 75: 3-18.

Souvannakhoummane, K., P. Souladeth, S. Tagane, C.-J. Yang and T. Yahara. 2019. Flora of Nam Kading National Protected Area VI: Didymocarpus middletonii (Gesneriaceae), a new species from limestone. Edinburgh Journal of Botany 76: 4554.

Souvannakhoummane, K. and P. Phonepaseuth. 2020. Didymocarpus albiflorus (Gesneriaceae), a new species from Vientiane capital, Lao PDR. Taiwania 65: 109-113.

Suddee, S., S. Tagane, P. Souladeth, D. Kongxaysavath, S. Rueangreua, Y. Suyama and E. Suzuki. 2020. Coleus bolavenensis (Lamiaceae), a new species from Laos. Thai Forest Bulletin (Botany) 48: 82-85.

Suetsugu, K., P. Souladeth, S. Tagane and T. Yahara. 2018. First 
record of the mycoheterotrophic orchid Lecanorchis taiwaniana from Nam Ha National Protected Area, northern Laos. Acta Phytotaxonomica et Geobotanica 69: 139-141.

Tagane, S., P. Souladeth, D. Kongxaysavanth, S. Rueangruea, S. Suddee, Y. Suyama, E. Suzuki and T. Yahara. 2020a. Two new species and 18 new records for the flora of Laos. Thai Forest Bulletin (Botany) 49: 111-126.

Tagane, S., P. Souladeth, A. Nagahama, Y. Suyama, N. Ishii, N. Tanaka and T. Yahara. 2020b. Twenty-five new species records in the Flora of Laos. Natural History Bulletin of the Siam Society 64: 25-41.

Tagane, S., P. Souladeth, S. Rueangruea, N. Okabe, M. Zhang, S. Chayer, C.-J. Yang, and T. Yahara. 2018a. Flora of Nam Kading National Protected Area II: 30 new records of angiosperms for Laos. Edinburgh Journal of Botany 75: 107-116.

Tagane, S., P. Souladeth, C.-J. Yang and T. Yahara. 2020c. Flora of Nam Kading National Protected Area VII: A new species of Diospyros (Ebenaceae), D. laoensis. Phytotaxa 477: 90-96.

Tagane, S., P. Souladeth, M. Zhang and T. Yahara. 2018b. Flora of Nam Kading National Protected Area IV: Two new species of Annonaceae, Monoon namkadingense and Neouvaria laosensis. Phytotaxa 336: 82-88.

Tanaka, N., S. Tagane and P. Souladeth. 2020. Zingiber collinsii Mood \& Theilade (Zingiberaceae), a newly recorded ginger from Laos. Thai Journal of Botany 12: 105-111.

Taylor, P. 1989. The genus Utricularia: A taxonomic monograph, Kew Bulletin Additional Series XIV. Royal Botanic Gardens, Kew, London, 736 pp.

Toyama, H., S. Tagane, P. Chhang, H. Nagamasu and T. Yahara. 2016. Flora of Bokor National Park, Cambodia IV: A new sec- tion and species of Euphorbia subgenus Euphorbia. Acta Phytotaxonomica et Geobotanica 67: 83-96.

Weber, A., D. J. Middleton, J. L. Clark and M. Möller. 2020. Keys to the infrafamilial taxa and genera of Gesneriaceae. Rheedea 30: 5-47.

Weber, A., D. J. Middleton, A. Forrest, R. Kiew, C. L. Lim, A. R. Rafidah, S. Sontag, P. Triboun, Y.-G. Wei, T. L. Yao and M. Möller. 2011. Molecular systematics and remodeling of Chirita and associated genera (Gesneriaceae). Taxon 60: 767-790.

Wu, Z., P. H. Raven and D. Hong. 1994-2013. Flora of China. Beijing, Science Press, Beijing and Missouri Botanical Garden Press, St. Louis, MO.

Yamazaki, K., P. Souladeth and S. Tagane. 2021a. Strobilanthes bolavenensis, a new species of Acanthaceae from Bolaven Plateau, southern Laos. Phytotaxa 513: 152-158.

Yamazaki, K., S. Tagane, P. Souladeth and J. Miyamoto. 2021b. A new variety, Justicia vagabunda var. laxiflora (Acanthaceae) from Bolaven Plateau, southern Laos. Acta Phytotaxonomica et Geobotanica 72: 161-166.

Yang, B., R.-B. Zhu, H.-B. Ding, S. Bouamanivong and Y.-H. Tan. 2020. A new species and two new records of Goniothalamus (Annonaceae) from Lao PDR. PhytoKeys 138: 17-25.

Yang, C.-J., S. Tagane, P. Souladeth, N. Okabe, J.-M. Hu and T. Yahara. 2018. Flora of Nam Kading National Protected Area III: Begonia namkadingensis (Begoniaceae), a new species in limestone area. Phytotaxa 334: 195-199.

Yang, L., C. Feng, M. Kang, and F. Wen. 2020. The taxonomic identity of Didymostigma trichanthera (Gesneriaceae). PhytoKeys 157: 191-197. 